\title{
Evaluation of Efficacy of Cabbage Juice (Brassica Oleracea Linne) As Potential Antiulcer Aggent and Its Effect on the Haemostatic Mechanism of Male Albino Wistar Rats.
}

\author{
Oguwike F.N ${ }^{1}$, Offor C.C ${ }^{2}$, Nwadighoha A.N ${ }^{3}$, Ebede S.O ${ }^{4}$, \\ 1. Department of Physiology, Faculty of Basic Medical Sciences, Anambra State University Uli, Anambra \\ State. \\ 2. Department of Medical Biochemistry, Faculty of Basic Medical Sciences, Anambra State University \\ Uli, Anambra State. \\ 3. Department of Public Health Imo State University Owerri, Imo State. \\ 4. Department of Medical Microbiology University of Nigeria Teaching Hospital Ituku Ozalla Enugu
} State.

\begin{abstract}
Ulcers are usually identified by abdominal pain, but this can be accompanied by vomiting red or black blood, blood in stool, unexplained weight loss and appetite changes (Corriher, 2010).

Evaluation of efficacy of cabbage juice (Brassica oleracea linne) as a potential antiulcer agent and its effect on the haemostatic mechanism of male albino wistar rats was studied using 42 male albino wistar rats.

The randomly selected animals of average weight were distributed into 3 groups $(A, B, C)$. Groups $B$ and $C$ were systematically induced with peptic ulcer before they were gavaged with the cabbage juice (Group B) and the standard ulcer drug (Group C).

Result of the study showed that cabbage juice healed ulcer fasted within 15 days compared to the standard cimethidin ulcer drug (28 days; Table 2). The bleeding and clotting times of test rats administered with cabbage juice were shorter than those on the standard ulcer drug and the corresponding control (Table 3).

The result also indicated that cabbage juice does not significantly affect on the haemapoietic systems since the results of all the complete blood count, carried out remained normal after at the end of extract feeding. It could be deduced that cabbage juice contains some antiulcer principles that prevents further breakage of the lining of gastroduon denal system,

Key Words:Ulcer, cabbage, homeostasis, haemoglobin, platelets, wistar rats.
\end{abstract}

\section{Introduction}

Over the years, the medical establishment has repeatedly changed its list of suspected causes for stomach ulcers (peptic ulcers).

At various times, ulcers have been blamed on stress (Corriher 2010), excessive alcohol consumption and more recently, genetic.

Ulcers are usually identified by abdominal accompanied by vomiting red or black blood, appearance of blood in the stool, unexplained weight loss and appetite changes.

A peptic ulcer is an excoriated area of the gastric mucosa caused by the digestive actions of gastric juice. The most frequent site of peptic ulcers is the pyloric region of the duodenum. It also occurs along the lesser curvature of the stomach or sometimes in the lower end of the esophagus where stomach juices frequently reflux. A peptic ulcer called "a marginal ulcer" also frequently occurs whenever an abnormal opening is made between the stomach and some portion of small intestine such as "gastrojejunostomy".

Included to the earlier mentioned causes of peptic ulcer are high acid peptic content, irritation, poor blood supply, poor secretion of mucus and infection (Oguwike 2013) by H. pylori.

The burden of frequent intake of antacids and antiulcer drugs with little or no relief from the suffering has given rise to curiously to find alternative to orthodox medication; hence the use of cabbage juice for the natural treatment of ulcer.

Cabbage is a popular cultivar of the species Brassica oleracea linne of the family Brassica (or Cruciferae) and is a leafy green vegetable. It is a herbaceous, biennial dicotyledonous flowering plant distinguished by a short stem upon which is crowded a mass of leaves, usually green but in some varieties red or purplish, which while immature form a characteristic compact, globular cluster (cabbage head). The only part of the plant that is normally eaten is the leafy-head; more precisely, the spherical cluster of immature leaves, excluding the partially unfolded outer leaves. Cabbage is used in a variety of dishes for its naturally spicy flavor. The so-called "cabbage head" is widely consumed raw, cooked, or preserved in a great variety of dishes. 


\section{CHEMICAL CONTENTS OF CABBAGE (Brassica oleracea)}

Carbohydrates $(5.8 \mathrm{~g})$, sugars $(3.2 \mathrm{~g})$, energy $(25 \mathrm{kcal})$, dietary fiber $(2.5 \mathrm{~g})$, protein $(1.28 \mathrm{~g})$, vitamin C $(44 \%)$, zinc $(2 \%)$, potassium (4\%), phosphorous (4\%), magnesium $12 \mathrm{mg} \mathrm{(3 \% ),} \mathrm{calcium} 40 \mathrm{mg}(4 \%)$, vitamin $\mathrm{B}_{6} 0.124 \mathrm{mg}$ $(10 \%)$, folate (Vit. $\left.\mathrm{B}_{5}\right), 53 \mu \mathrm{g}(13 \%)$.

\section{MEDICINAL VALUE OF CABBAGE:}

Cabbage is a good source of Vit. $\mathrm{C}$ which helps in fastening the healing of wounds. It also contains significant amounts of glutamine which is an amino acid that has anti-inflammatory properties.

In conjunction with broccoli and other Brassica vegetables, cabbage is a source of indole-3-carbinol, a chemical which boosts DNA repair cells and appears to block the growth of cancer cells (BBC, 2006). Boiling reduces anticancer properties (Warwick 2007). Cabbage is claimed to be effective in relieving painfully engorged breasts in breast feeding. Fresh cabbage juice has been shown to promote rapid healing of peptic ulcers (Cheney, 1949), thus restoring homeostasis in the internal body environment.

\section{MATERIALS AND METHODS:}

The lethal dose $\left(\mathrm{LD}_{50}\right)$ of the extract of cabbage and phytochemical analysis for the constituents of the plant extract were studied before the haemostatic, haematological and its potency as antiulcer agent were experimented.

\section{ANIMALS:}

Forty-two healthy adult male albino rats of Wistar strain weighing between 200-220g were used in the study. The animals were housed under standard conditions of temperature $\left(23 \pm 2^{\circ} \mathrm{c}\right)$ and humidity; receiving $12 \mathrm{~h}$ light $(7.00 \mathrm{am}-7.00 \mathrm{pm})$. They were kept in wire meshed cages and fed with commercial pellets (Guinea feed) and drinking water ad libitum. The animals were handled in accordance with National and Institutional Guidelines for the Protection of Animal welfare.

\section{EXPERIMENTAL DESIGN:}

The animals were randomly assigned into three groups of 14 rats each. Group A serve as control and was treated with normal saline. Group B (Induced peptic ulcer rats on cabbage juice) and Group C (induced peptic ulcer rats on standard cimetidine tabs).

\section{PREPARATION OF EXTRACT:}

Fresh leaves of cabbage were purchased from Afor Ogwa market, Mbaitolu.

The botanical identification and authentication was confirmed at the Department of Biological Sciences, Anambra State University Uli. The leaves were washed properly. The fresh leaves were crushed to semiaqueous form using a mechanical blender. It was stored in a glass bottle with a plastic screw cap and kept in a refrigerator $\left(4^{0} \mathrm{c}\right)$. The leaves were homogenized with distilled water by shaking and kept for $12 \mathrm{hrs}$. The mixture was filtered with Whatman No.1 filter paper. The filtrates were concentrated to one-tenth $(1 / 10)$ of the original volume at $38-40^{\circ} \mathrm{c}$ using a rotary evaporator. The aqueous extract was freeze dried yielding a white powder $0.5 \mathrm{~g}$ of the powder was resuspended in $100 \mathrm{ml}$ of distilled water before use (Ugochukwu et al 2003). $5 \mathrm{mg} / \mathrm{kg}$ of the extract was administered to the rats with blunt sterile needle while giving them their normal rat pellets and drinking water ad libitum.

\section{PHYTOCHEMICAL ANALYSIS OF CABBAGE:}

The crushed out cabbage juice was screened for the presence or absence of various secondary metabolites that could be of therapeutic values using standard phytochemical screening procedures described by Harbourne (1973), Trease and Evans (1996). The extract was tested for Glycosides, flaveniods, alkaloids, tannins, reducing sugars, calcium, saponins, acidic compounds, resins, fats and oils, carbohydrate and steroids.

\section{TOXICITY STUDIES $\left(\mathbf{L D}_{\mathbf{5 0}}\right)$ :}

The $\mathrm{LD}_{50}$ of the extract in albino rats was determined using Lorke's method (1981). The procedure of determining the lethal dose is by increasing the concentration of the extracts administered into rats (after weighing them) in each group consisting eight ( 8 rats) per group for five (5) days. The concentration given its at the rate of $1000 \mathrm{mg} / \mathrm{kg}, 1500 \mathrm{mg} / \mathrm{kg}, 2500 \mathrm{mg} / \mathrm{kg}, 3000 \mathrm{mg} / \mathrm{kg}, 3500 \mathrm{mg} / \mathrm{kg}, 4500 \mathrm{mg} / \mathrm{kg}$ and $5000 \mathrm{mg} / \mathrm{kg}$. The percentage is noted and a graph plotted to determine the $\mathrm{LD}_{50}$. 
$\mathrm{LD}_{5} \lambda=$ Dose killing all animals in the group $\mathrm{x}$ dose.

Killing none of the animals in the groups.

The haemoglobin estimation ( $\mathrm{g} / \mathrm{dl}$ ) was determined by cyanmetha-haemoglobin method as described in Baker et al 1985. The packed cell volume estimation was determined by the simple method of microhaematocrit centrifugation method (Baker et al 1985). The total white blood cell count and differentials were also determined by method of Baker et al 1985. The platelet count estimation was done by method of Brecher (1950). The whole blood clotting time was estimated by the method of Lee and White as described in Baker 1985. The bleeding time was determined by the method of Dejana et al, 1982.

\section{INDUCTION OF PEPTIC ULCER IN RATS (SHAY'S METHOD):}

A new method has been developed for producing ulcers in rats (Weischer et al 1983). Peptic ulcers can be induced in the pylorus using Shay's method as noted in Weischer's work. Ligation of the pylorus induces ulcers that serve as a useful model for investigating the efficacy of drugs on gastric secretions. The ligation of the pyloric end of the stomach causes accumulation of gastric acid in the stomach that produces ulcers. These ulcers result from auto-digestion of the gastric mucosa leading to a breakdown of the gastric mucosal barrier. So basically an increase in acid-pepsin accumulation due to pylorus obstruction may cause subsequent mucosal digestion. The model is useful for assessing the cytoprotective effects of drugs that increase secretion of mucus. Animals are fasted for 36-72hrs prior to pylorus ligation. In this model, the pylorus is ligated by means of the 'Shay' technique under either anesthesia. The drug or test material is administered orally one hour before the pylorus is ligated. The animals are killed 18-20 hours later and ulcers are assessed.

\section{DETECTION OF ULCER IN TEST RATS:}

Rather than killing the animals after induction of ulcer in the pylorus using ligation, ulcers can be detected in test animals using their stool samples and performing occult stool test. In this method as described by Baker et al 1985, stool samples from the test animals in Groups B and C were collected and little quantity was emulsified on a test paper as a thin smear. One okokit tablet (occult tablet) is then placed in the center of the smear.

Three drops of diluents are then applied onto the tablet. After 2 minutes, a further three drops of the diluents is added. Then the result is read after $5 \frac{1}{2}$ minutes for presence of blood in the stool.

The peroxidase activity of haemoglobin and its iron-containing derivative catalyze the oxidation of the noncarcinogenic chromogen to form a blue colour in the presence of hydrogen peroxide.

Occult stool test using the faeces of the test rats, was carried before the administration of the cabbage juice after inducing ulcer and at the end of 28 days feeding with the extracts to check that ulcer was healed with the application of the extract.

\section{COLLECTION OF BLOOD AND FAECAL SAMPLES AND DURATION OF STUDY:}

$2.0 \mathrm{ml}$ of blood sample was collected from each rat in all the groups into EDTA bottle to determine the initial blood pictures before feeding them on the extracts. Their weight, full blood count (FBC) including platelet count, bleeding time and clotting time was assessed. At the end of the acute study (28 days) of feeding on the extract, blood samples were again obtained from the animals by cardiac punctures for the haemostatic and haematological analysis as was done initially.

Faecal samples of the animals were collected before ulcer induction, after ulcer induction and at the end of administering the ulcered test animals with the cabbage juice $(0.5 \mathrm{mg} / \mathrm{kg})$.

\section{Statistical Analysis:}

The data obtained from the study were expressed as Mean and Standard deviation (Mean \pm S.D) while students' T-test was used to compare the result of the control and the test. A P-value of less than or equivalent to $(\mathrm{P}<0.05)$ or $(\mathrm{P}=0.05)$ was noted as statistically significant. 


\section{Results \\ TABLE 1:}

Shows the phytochemical analysis of cabbage juice.

\begin{tabular}{|l|c|l|c|c|c|l|}
\hline & \multicolumn{9}{|c|}{} & $\begin{array}{l}\text { Carbohydrate } \\
\text { Alkaloids }\end{array}$ & $\begin{array}{l}\text { Acidic } \\
\text { compounds }\end{array}$ & $\begin{array}{l}\text { Flavenoids } \\
\text { Tannins } \\
\text { Fats and oils } \\
\text { Steroids } \\
\text { Terpenoids }\end{array}$ \\
\hline $\begin{array}{l}\text { Degree } \\
\text { Concentration }\end{array}$ & + & - & ++ & +++ & ++ & - \\
\hline
\end{tabular}

- $\quad$ Negative (absent)

$+\quad$ Present in moderate high concentration

$++\quad$ Present in moderate high concentration

$+++\quad$ Present in very high concentration.

TABLE 2:

Shows the effect of cabbage juice on duration of peptic ulcer healing in Male albino rats compared to their corresponding controls. Cabbage juice fastened healing more than standard peptic ulcer drug $(\mathrm{p}<0.05)$.

\begin{tabular}{|l|l|c|c|}
\hline Groups & Extract & Days & P. Value \\
\hline Group A (controls) $\mathrm{n}=14$ & Normal saline & - & - \\
\hline $\begin{array}{l}\text { Test Rats. 30 days after extract } \\
\text { juice Group B } \mathrm{n}=14 .\end{array}$ & Cabbage juice & $15 \pm 0.24$ & $\mathrm{P}<0.05$ \\
\hline $\begin{array}{l}\text { Group C } \mathrm{n}=14 \quad 30 \quad \text { days } \\
\text { cimetidine administration. }\end{array}$ & Cimetidine tabs & $28 \pm 0.5$ & $\mathrm{P}<0.05$ \\
\hline
\end{tabular}

TABLE 3: Shows the effect of cabbage juice extract on complete blood count, platelet count, platelet count, bleeding and clotting times of albino wistar rats.

\begin{tabular}{|c|c|c|c|c|c|}
\hline Extracts & $\begin{array}{l}\text { Hbg/dl Mean } \\
\pm \text { S.D }\end{array}$ & $\begin{array}{l}\text { PCV 1/1 Mean } \\
\text { S.D }\end{array}$ & $\begin{array}{l}\text { Platelet count } \mathrm{x} \\
10^{9} / 1 \pm \text { S.D }\end{array}$ & $\begin{array}{l}\text { Bleeding time } \\
\text { min } \pm \text { S.D }\end{array}$ & $\begin{array}{l}\text { Clotting time Min } \\
\pm \text { S.D }\end{array}$ \\
\hline $\begin{array}{l}\text { Group A Control rat } \\
\text { (Extract free) } n=14\end{array}$ & $14.5 \pm 1.5$ & $43.0 \pm 4.6$ & $186 \pm 37$ & $2.7 \pm 0.2$ & $5.4 \pm 0.8$ \\
\hline $\begin{array}{l}\text { Test Rats Group } \mathrm{N} \\
(\mathrm{n}=14) \text { Day } 1 \text { before } \\
\text { cabbage juice }\end{array}$ & $14.2 \pm 0.8$ & $43 \pm 2.4$ & $184 \pm 52$ & $2.6 \pm 0.3$ & $5.2 \pm 0.6$ \\
\hline $\begin{array}{lr}30 \quad \text { days } & \text { after } \\
\text { administration } & \text { of } \\
\text { cabbage juice. } & \end{array}$ & $14.0 \pm 1.6$ & $42.0 \pm 4.2$ & $182 \pm 49$ & $1.8 \pm 0.2$ & $4.0 \pm 0.2$ \\
\hline $\begin{array}{l}\text { Group }(\mathrm{n}=14) \text { Day } 1 \\
\text { before cimetidine } \\
\text { administration }\end{array}$ & $14.3 \pm 0.6$ & $42.0 \pm 1.9$ & $188 \pm 54$ & $2.6 \pm 0.3$ & $5.2 \pm 0.5$ \\
\hline $\begin{array}{ll}30 \text { days after } \\
\text { cimetidine } \\
\text { administration. }\end{array}$ & $13.9 \pm 1.2$ & $40 \pm 3.6$ & $180 \pm 42$ & $20 \quad \pm 0.2$ & $4.5 \pm 0.3$ \\
\hline P-value. & $\mathrm{P}>0.05$ & $\mathrm{P}>0.05$ & $\mathrm{P}>0.05$ & $\mathrm{P}<0.05$ & $\mathrm{P}<0.05$ \\
\hline
\end{tabular}

TABLE 4: White blood cell counts and differentials in albino rats before the administration of cabbage juice.

\begin{tabular}{|c|c|c|c|c|c|c|}
\hline Extract & $\begin{array}{l}\text { WBC } / \mathrm{mm}^{3} \pm \\
\text { S.D }\end{array}$ & $\begin{array}{l}\text { N\% } \\
\text { S.D }\end{array}$ & L\% \pm S.D & $\mathrm{M} \% \pm \mathrm{S} . \mathrm{D}$ & $\mathrm{E} \% \pm \mathrm{S} . \mathrm{D}$ & B $\% \pm$ S.D \\
\hline $\begin{array}{l}\text { Group A (control Rats ) } \\
n=14 \text { Extract Free }\end{array}$ & $5,250 \pm 360$ & $51 \pm 0.3$ & $46 \pm 0.4$ & $2 \pm 0.4$ & $1 \pm 0.3$ & \\
\hline TEST RATS & \multirow[b]{2}{*}{$5,320 \pm 260$} & \multirow[b]{2}{*}{$53 \pm 0.5$} & \multirow[b]{2}{*}{$44 \pm 0.3$} & \multirow[b]{2}{*}{$2 \pm 0.2$} & \multirow[b]{2}{*}{$1 \pm 0.2$} & \multirow[b]{2}{*}{$0 \pm 0$} \\
\hline $\begin{array}{l}\begin{array}{l}\text { Day } 1 \text { before cabbage } \\
\text { juice administration } \\
\text { Group } \mathrm{B} \mathrm{n}=14\end{array}\end{array}$ & & & & & & \\
\hline Group C $n=14$ & $5,200 \pm 260$ & $52 \pm 0.7$ & $44 \pm 0.2$ & $2 \pm 0.4$ & $2 \pm 0.5$ & $0+0$ \\
\hline $\begin{array}{ll}30 \text { days } & \text { after cabbage } \\
\text { juice } & \text { administration } \\
\text { Group } B \quad n=14\end{array}$ & $5200 \pm 205$ & $50 \pm 0.6$ & $46 \pm 0.4$ & $3 \pm 0.2$ & $1 \pm 0.2$ & $0 \pm 0$ \\
\hline $\begin{array}{l}30 \text { days after cimetidine } \\
\text { administration Group C } \\
\mathrm{n}=14\end{array}$ & $5280 \pm 180$ & $52 \pm 0.4$ & $45 \pm 0.2$ & $2 \pm 0.1$ & $1 \pm 0.5$ & $0 \pm 0$ \\
\hline P-value & $\mathrm{P}>0.05$ & $\mathrm{P}>0.05$ & $\mathrm{P}>0.05$ & $\mathrm{P}<0.05$ & $p>0.05$ & $p>0.05$ \\
\hline
\end{tabular}

$\mathrm{N}=$ Neutrophilis, L= Lymphocytes, $\mathrm{M}=$ Monocytes, E= Eosinophilis, 
$\mathrm{B}=$ Basophilis

FIGURE 1:Lethality studies showing the effects of administering graded doses (1000-5000mg/kg ip rat) of the cabbage juice against the percentage mortality.

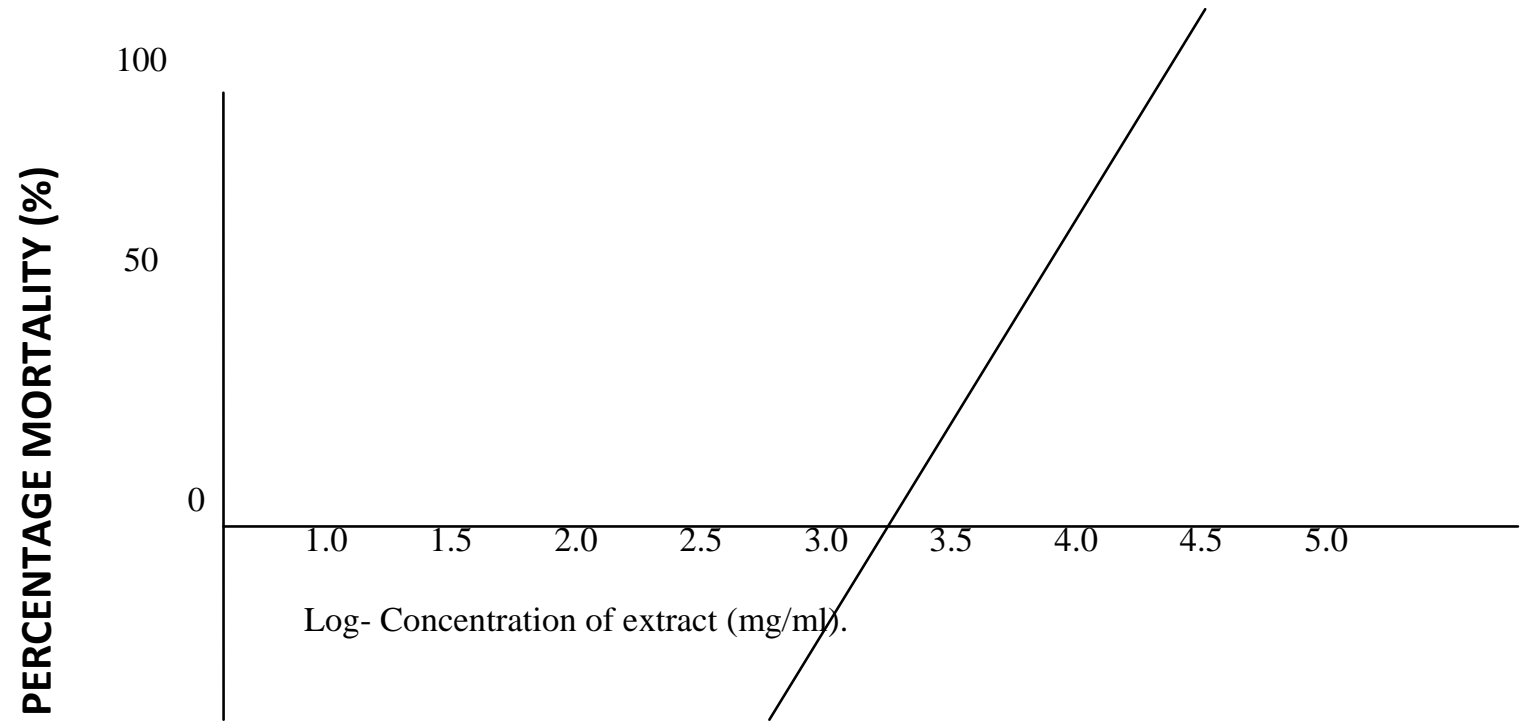

\section{Discussion}

The efficacy of cabbage (Brassica oleracea) juice extract as a potential antiulcer agent and its effect as a potential antiulcer agent and its effect on the haemostatic mechanism of Male albino wistar rats has been evaluated. Peptic ulcer is among the most serious gastrointestinal diseases in the world. Several orthodox drugs are employed for the treatment of the disease (Buenor et al 2013). Although these drugs are effective, they produce many adverse effect thus limiting their use in recent years. There has been a growing interest in plants with ethno medicinal values as alternative therapies in peptic ulcer. The activities of cabbage juice in influencing the healing of ulcer and restoring the normal haemostatic mechanism of albino wistar rats can ever be overemphasized. Most times plant extracts are given to humans in excessive doses by the ethno medicinal practitioners.

Toxicity may affect the result of this study and so acute toxicity studies using $\mathrm{LD}_{50}$ were carried out before the extract was administered to the test animals in groups B and C. The result of lethality studies showed that the $\mathrm{LD}_{50}$ in rats using cabbage juice extract was $3500 \mathrm{mg} / \mathrm{kg}$ (Fig 1). The doses used in this study $(5 \mathrm{mg} / \mathrm{kg}$ ) was far below the lethal dose and so was considered safe to the animals used throughout the period of the study. Peptic ulcers which occurs as a result of break in the lining of the gastrointestinal mucosa bathed by acid and pepsin was healed in the rats with 16 days of administration to group B rats (table 2) $\mathrm{p}<0.05$ compared to Group $\mathrm{C}$ rats (28 days) which were placed on the standard cimethidine orthodox ulcer drugs.

The ulcer healing factor present in cabbage is known as S. methymethionine or simply vitamin U (Corriher, 2010). It could be that this vitamin prevented further acid erosion and peptic digestion of the lining of the gastrointestinal mucosa and the healing was accelerated by the presence of calcium in the juice of cabbage (Table 1).

Calcium contained in this plant extract are known to be involved in the precipitation of coagulation factors (Taofaeeq et al, 2005) for clotting to occur fast. Vitamin $\mathrm{K}$ is also present in the juice that helps to control bleeding.

In this study, there was no significant decrease in the haemoglobin concentration, $(\mathrm{P}<0.05)$, packed cell volume, platelet count, white blood cell count and differentials (table 3).

This points to the safe use of the cabbage juice in both rats and human body system. The bleeding and clotting times were reduced (Table 3) in Group B indicating active principles probably calcium and vitamin U present in the cabbage juice affecting the coagulation system.

\section{References}

[1]. BAKER F. J, SILVERTON R.E (1985): Investigation for haemostatic abnormalities; Introduction to Medical Laboratory Technology Pp 348. Butterworths Publication Worburn London.

[2]. BAKER F. J, SILVERTON R.E (1985). Gastric and Pancreatic Function test. Introduction to Medical Laboratory Technology pg 117-118. Published by Butterworths Company Melbourne

[3]. “BROCCOLI CHEMICALS' CANCER CHECK” BBC News, 7 February 2006. Retrieved 5 September, 2010. 
[4]. BUENER A, ANSAH C, GALYOUN I, NYARKO A (2013). Invivo models used for evaluation o potential antigastroduodenal ulcer agents. http://dx.doi.org/10.1155/2013/796405.

[5]. CHENEY G (1949). "Rapid healing of peptic ulcers in patients receiving fresh cabbage juice" California Med 70 (10):10-5, PMC 1643665. PMID 18104715 .

[6]. CORRIHER S.C (2010). Quick Tip: Cure ulcers naturally with Raw Cabbage Juice Facebook 2010.

[7]. HARBOUNE J.B.C (1973): Phytochemical methods Chapman and Hall, London p276.

[8]. LORKE D, (1983). A new approach to practical acute toxicity testing. Arch. Toxical 54:275-278.

[9]. OGUWIKE F.N (2013). "Peptic ulcer" comprehensive Medical Physiology pg 116 Published by Idealway Publications Nigeria 39 Nike Road Enugu Nigeria.

[10]. TAOFEEQ O, OYENIYI M. A, TESLEEN A.O (2005). Mechanism of action of Jathropha Gossypifolia stem latex as a haemostatic agent. European Journal of General Medicine.

[11]. TREASE G. F and EVANS W. C (1996). Textbook of pharmacognosy, $14^{\text {th }}$ Ed. W. B Sauders London Pp 46-47, 832.

[12]. UGOCHUKWU N. H, BABADY N. E, COBOURNE M, GASSET S. R (2003). The effect of Gongronema latifolium (Utazi) on the serum lipid profile and oxidative stress in hepatocytes of diabetic rats. Journal of Biosciences 28 (1) 1-5.

[13]. WARWICK Medical School, University of Warwick (2007-05-15). 'Research says Boiling Broccoli Ruins its Anti cancer Properties.

[14]. WEISCHER C. H, THHIEMER K (1983). A method for induction of cols, indomethacin and restraint ulcders in rats. Methods Find Exp Clin. Pharmacol, 1983 June: 5(5): 315-9. 